for a very efficient solution to safe bears, wildlife and habitats in general, and in Alberta in particular. The scandalous oil sand issue is not mentioned, nor the Cadomine mine and hunting attitude fully tolerated by University research in Edmonton; Climate Change got also somewhat played down in the text. Impacts brought by globalization, as well as the poaching demands from China should have been mentioned.
"Oh Canada": she is currently in big turmoil, and right now is the time for a major improvement, instead of "...a cowardly abdication of its legal obligation" and global responsibilities.

FALK HuETtManN

EWHALE lab, Institute of Arctic Biology, Biology \& Wildlife Department, University of Alaska-Fairbanks (UAF), Alaska 99775 USA

\title{
Birds of Canada
}

By David M. Bird. 2010. Dorling Kindersley, (Represented by) Tourmaline Editions Inc., 662 King Street West, Suite 304, Toronto, Ontario M5V 1M7 Canada. 512 pages. \$40 CAD.

Primarily covering the most common species in Canada, this photographic guide by David M. Bird (Director of Avian Science and Conservation at McGill) provides an excellent starting point for newcomers to both bird watching and the "Great White North". As a young, British ecologist, newly arrived from the rainforests of Ecuador, this book offered me a welcome introduction to the birds of North America.

In developing my interest in birds, I have previously used field guides containing illustrations rather than photos (Collins Bird Guide: The Most Complete Guide to the Birds of Britain and Europe by Svensson \& Grant, and Birds of Ecuador by Ridgeley \& Greenfield). Whereas illustrations and line drawings can simplify the key identification features, I initially found the photographs in Birds of Canada to be over-detailed and confusing, particularly with families such as the American Sparrows, Thrushes and the Wood-Warblers. However, the clear labelling provides excellent guidance to the important visual cues and the accompanying illustrations highlight things to look for in flight. The extra photographs of alternative/seasonal plumages and sexual dimorphism are useful, although on occasion seem to be lacking. More could also be made of subspecies and morphs, but perhaps this would be confusing for the newcomers that this book seems to be aimed at.

The first few pages provide a solid background to birds, describing their evolution, anatomy, flight, migration, courtship and reproduction. I found these sections to be clear and thorough, offering information appropriate to children, adults, novices and seasoned amateurs alike. There is also an excellent section detailing the main components of field identification and describing how to use the book. Introduction pages to each of the main groups provide an excellent starting point, illustrating features common throughout the families and describing general behaviours.

Each page thereafter is devoted to one of each of 435 commonest species in Canada (30 rarer species are presented later, four to a page). The large photographs and 1-page-per-species approach results in the book being much larger than it could have been. I also found this to slow up the process of identification, as you have to turn through many pages upon seeing an unrecognisable bird in the field, in comparison to other books which show multiple, closely-related species on one page (Birds of Ecuador, Peterson Field Guide to Birds of North America by Roger Tory Peterson). There are diagrams provided to illustrate flight patterns: a functional extra which I have not seen in other field guides. The maps on each page illustrate North and Central America as a whole, which is a nice way to learn about a bird's migration patterns, but the maps are small and it can take a while to determine the exact status of birds in the Maritimes or Southern Ontario for example. Adequate descriptions are used for songs and calls (never an easy task), although I did find more could have been included to do with the length of the notes (Black Capped Chickadee for example).

I liked the way in which the classification, size, social units, lifespan and (of particular value to me) conservation status for each species is clearly presented. Another nice touch is the box found on each page depicting two of the most likely species to confuse a newcomer. However, I did notice one or two instances of poor correlation. Despite the fact that on the Wood Thrush page, the Hermit Thrush is shown as being a potentially confusing species, there is no mention of the former on the latter's page. There is also the case of Boat-Tailed Grackle, which is shown as a similar species to the Common Grackle, but receives no mention among the rare or vagrant species, and according to other sources is quite unlikely to turn up in Canada.

There also appears to be a few errors in the distribution and status descriptions of the main birds. For example, there is no mention of the Burrowing Owl's precarious state in Canada, or of the recovery program that is being implemented to prevent its decline. Laughing Gulls are included among the 435 common species, but the map shows their only Canadian occurrence is during migration in parts of New Brunswick and Nova Scotia. There is no mention of the increases 
in numbers of Ravens, Cardinals and Canada Geese, nor is the drop in Evening Grosbeaks and Brown Creepers noted.

The long list of vagrants (147) serves as a useful point of reference for incidences of confusion, and highlights how parts of Canada are blessed by an array of species during the migration season. Images could have been useful in this section, but would have increased the size of book further, and you can always look up these species online or in other guides. The comprehensive glossary that completes Birds of Canada is highly valuable to beginners. The index could have benefited from being split into common and scientific names.
Bulky, weighty and at times awkward to negotiate, I feel that this book is of no use in the field (despite the fact that it is lighter than Birds of Ecuador, which covers some 1600 species!). Birds of Canada however does serve as the perfect reference to leave at home and cross check against other field guides, which usually cover both the USA and Canada. Containing beautiful close-up's for identification in addition to photos of the birds in their natural habitat, I think that this book is of particular use to families and individuals developing an interest in bird watching, and is probably less valuable to those that can already describe themselves as "birders".

MatThew ILES

1431 Lakeshore Road, Apartment 308, Burlington, Ontario L7S 1B4 Canada

\section{The Birds of Dalian: With Special Focus on Jinshitan National Holiday Resort}

By T. Beeke. 2010. Bing Long Books. 180 pages. 98 Yuan (RMB). Available from the author (jinshitanbirding@yahoo.ca)

Naturalists worldwide play a great role in the documentation and conservation of species and habitats. This book presents us with such an heroic effort by a skilled naturalist. The Canadian author T. Beeke from British Columbia and living in China for over 6 years has just published a valuable and professional book documenting the avian diversity of a global birding spot: Dalian, located at the Northeastern Yellow Sea. As this nice little field guide shows, the Dalian region is home to c. 400 bird species, and of interest to birders year round (nesting season, fall and spring migrations, as well as a wintering ground). All of the featured species get described with three locally taken photos (usually in flight, perching and zoomed-in), with a descriptive text, and also showing the occurrence and species status in the area.

Besides its ice-free port, Dalian is also known for its Holiday Resort which has attracted tourists for decades. Bird sightings from adjacent areas and huge wetlands such as Lushun, Pikou, Zhuanghe, Wafangdian and Dandong are also included in this book. The current speed of development and contamination in China, and specifically in this region, is (literally) breathtaking: crucial nesting and stop-over habitats simply disappear within less than a year, and in front of the birder's eye! The devastating effects of a ruthless Global Economic Growth become obvious again. Another feature that makes Dalian known to birders is its species diversity, and the abundance of many migratory shorebirds; e.g., from Russia and Australia. Further, several international Arctic (!) gulls can be found wintering in the region (Vega Gull, Heuglin's Gull, Glaucous Gull).

The book is nice to read and does not claim to be a scientific treatise: instead it is designed for the beginner and even for interested school kids. Birders new to the area (and to the Chinese landscape) will benefit greatly from the four opening pages dealing with "Areas to look for birds: Forested Mountains, Coastal Mudflats, Agricultural Areas, Lakes, Ponds and Rivers". Among the over 180 species covered are for instance the beautiful Chinese cranes, egrets, raptors, warblers, flycatchers, thrushes, shrikes, buntings and the confusing warblers and pipits. Because up to 400 species occur in the area, a few more relevant species can probably be added to the book, and will make it into the next edition then (e.g., Coots, several Owls, Pied Harrier, Black Stork, Marsh Sandpiper, Siberian Rubythroat). But the endangered species such as Chinese Egret, Black-faced Spoonbill and Chinese Hill Warbler are also well featured by the author. The three page index of common English names proves helpful in the field (the author followed his own taxonomy).

"This book was put together with the goal of inspiring people to notice the birds around them". It's nice to learn that the locally involved author plans eventually for a Chinese (Mandarin) version of this neat book, and so that the local community can better appreciate its own natural wealth, and before it is all too late, over-developed and destroyed. So many of the formerly healthy and diverse landscapes in China are already widely impoverished and now lack their original set up: Huge regions are just dominated by domestic chicken, magpies, tree sparrows and common pheasants. In times of a massive globalization, the Dalian region and its precious biodiversity and documentation provided by an international Naturalist deserves our attention, support and protection.

FALK HuETTMANN

EWHALE lab, Institute of Arctic Biology, Biology \& Wildlife Department, University of Alaska-Fairbanks (UAF), Alaska 99775 USA 